\title{
A FIELD STUDY OF THE TRANSACTIONAL MODALITIES OF THE IN-SERVICE TEACHER TRAINING PROGRAMMES FOR SECONDARY SCHOOL TEACHERS UNDER RMSA IN MIZORAM
}

\author{
Zairemmawia Renthlei, \\ Research Scholar, Dept of Education, Mizoram University \\ Prof. L N Mishra \\ Professor, Dept of Education, Mizoram University;
}

Article DOI: https://doi.org/10.36713/epra5193

\begin{abstract}
-
The professional development of teachers is an important aspect of education and the main avenue for the professional development of secondary school teachers is the in-service training programmes organised by the district education offices. This study is an attempt to study the transactional modalities i.e. the manner in which the training programmes are organised by the various district education offices. Training Centres in all eight districts of Mizoram were visited and administrative staff from all the district offices were interviewed. Findings were tabulated and recommendations made for improvement.
\end{abstract}

KEYWORDS: In-service Training Programme, Secondary School Teachers, Training Centres, Transactional Modalities, Challenges, Thrust Areas, Recommendations.

\section{INTRODUCTION}

It has often been said that 'Teachers are the builders of the nation'. The importance of teachers in directly and indirectly shaping the present and future of our country is beyond contention and argument. The quality of teachers therefore determines to a very large extent the quality of education in our country and the continuous professional development of our teachers is a necessity to keep up with the dynamic nature of society and education.

In India the responsibility for the continuous professional development of school teachers falls mainly upon the Central Schemes such as Sarva Shiksha Abhiyan (SSA) and Rashtriya Madhyamik Shiksha Abhiyan (RMSA) which have taken up the mandate by financing annually the in-service training programmes for school teachers. For the secondary stage, in-service training of teachers is annually organised by Rashtriya Madhyamik Shiksha Abhiyan for a duration of 5 days for each subject teacher.

In Mizoram, the training programmes are conducted/organised by the District Education Offices where the DEOs are the District Project Coordinators and are assisted by Deputy District Programme Coordinators and other staff. The teachers are gathered at the district headquarters in a suitable venue where the training takes place. Various resource persons from different agencies and institutions are invited to lend their expertise for the training programmes.

Mizoram is one of the remotest states in India and is still plagued by a variety of maladies in education and teacher education as well. Mizoram had 8 districts at the time of the study namely Aizawl, Champhai, Kolasib, Lawngtlai, Lunglei, Mamit, Siaha and Serchhip. Some of these districts may be classed as educationally backward with poor performance of students and a general lack of infrastructure and facilities including manpower. Hopefully, this study will shed some light into the problem areas regarding the in-service training programmes for secondary teachers in Mizoram under RMSA. 


\section{NEED OF THE STUDY}

This study aims to examine the manner in which the in-service training programmes for secondary school teachers under RMSA are organised in the State of Mizoram. The success of any programme lies to a great extent on the manner in which it is organised and managed. A professional and efficient transaction is very important to achieve optimum results in the training programmes as well as to circumvent any possible loopholes that may arise.

In addition, the various challenges or difficulties that are encountered in the organisation and management of the training programmes needs to be identified with a ground-level investigation so as to develop means to overcome these challenges. Also, the future roadmap of the training programmes needs to be charted out through identification of possible thrust areas so that the training programmes remain relevant in the future. Lastly, possible remedies of the difficulties as well as measures to affect qualitative improvements must be worked out which will help the in-service training programmes meet the need of the secondary school teachers which will in turn affect the educational development of their students in a positive manner.

\section{OBJECTIVES OF THE STUDY}

1. To examine the transactional modalities of the in-service training programmes for secondary school teachers in Mizoram.

2. To assess the challenges facing the in-service training programmes.

3. To identify possible thrust areas for the in-service training programmes.

4. To make necessary recommendations for improvement of the training programmes.

\section{METHODOLOGY}

For the purpose of collecting information and related data for the study, the investigator visited all the districts at the actual locations where the training programmes were conducted. The investigator met and interacted with various officials from the district education offices such as Deputy District Project Coordinators, Counsellors, Office Assistants, etc. The investigator conducted formal interviews in all the district training centres with personnel who were directly involved with the organisation and management of the programmes under study with the help of an interview schedule. The interviews were recorded digitally which were later transcribed and translated into English. The data was analysed qualitatively.

\section{A. Transactional Modalities}

\section{FINDINGS}

The in-service training programme for secondary teachers was initiated as a part of the Rashtriya Madhyamik Shiksha Abhiyan umbrella to ensure quality education in the secondary schools of India through the continuous professional development of teachers through in-service contact programmes. The Programme Advisory Board of the RMSA had the mandate for the overall administration of the training programmes as well as the allocation of the necessary funds to the states.

At the State level, the in-service training programmes were directed and overseen by the State Project Directors office which disbursed the necessary funds to the districts as soon as they were sanctioned from the National Project Mission Offices. In Mizoram, a separate RMSA wing under the Director of School Education who also functioned as the State Project Director was created with staff drawn from the Directorate of School Education as well as RMSA personnel. The State Project Offices also acted as the link between the National and District levels, passing on guidelines and relevant information whenever necessary. The State Project office is the main nerve centre for the whole state and coordinates all the efforts of the eight districts and consolidates the data accumulated from all over the state.

At the District level, The District Education Officer acted as the District Project Coordinator and was assisted by the Deputy District Project Coordinator. The Deputy District Project Coordinator was usually deputed from among the serving district office staff or in most cases, from headmasters or senior teachers of secondary schools. The RMSA project offices were placed adjacent to the District Education Offices and often functioned parallelly and are usually manned by staff recruited through RMSA in various capacities.

In most districts, the training programmes are conducted at the back-end of the calendar year which usually coincides with the third or fourth quarters of the academic sessions. Usually, the programmes are initiated as soon as funds are sanctioned from the state project offices. However, sometimes the funds are sanctioned very late and the training programmes are initiated before the actual sanction of funds. In such cases, the expenditure is met from other sources and later recovered/recouped from the sanctioned funds.

At the onset, the district project staff formulates the training routines and identifies possible venues for the training programmes as well as the necessary resource persons for the various topics identified for the programmes. Mention must be made here of the situation in Aizawl district which was found to be different from the rest of the state. For the case of Aizawl district, the National Project offices had identified Institute of Advanced Studies in 
Education (IASE) and National Institute of Technology (NIT) as Nodal Institutions for the in-service training programmes specifically for Aizawl District so all formalities such as venues, resource persons, training schedules, etc. are arranged in consultation with faculty members of these institutions. Letters are then issued to the secondary school headmasters informing them of the timing and schedule of the training programmes as well as advising them to send the appropriate teachers for the training programmes as per the schedules devised by the district offices.

The training programmes are usually conducted for five weeks with three to five working days scheduled in the routines. Due to difficulties in transportation from remote areas and the non-availability of such services on Sunday, most districts find it difficult to conduct training programmes for the full five days. Most districts schedule programmes spanning four days while a few districts manage four and a half days. An aberration to the trend was observed in Siaha District where a severe shortage of teachers has compounded the problem to such a degree that the absence of one or two teachers from a school makes it practically impossible to manage the daily workings of the school in many cases. In order to minimise the impact of the training programmes on the daily management of the schools, training programmes for all the five subjects are conducted simultaneously at the same time. During this time, the schools are closed as all the teachers attend the training programmes. In Siaha, the training programmes usually last $2-4$ days.

Training Centres in the districts vary from the air-conditioned classrooms of NIT, Aizawl to the school classrooms of Siaha, Serchhip, Mamit, etc. Block Resource Centres, Conference Centres, various Departmental Halls are also utilised for the training programmes subject to their availability at the time of the training programmes.

Resource persons are invited from a myriad number of sources and the quality greatly differs from district to district. Aizawl District, as expected, has access to extremely qualified resource persons including Mizoram University, IASE, NIT, SCERT, DIET Aizawl, Various Degree Colleges, etc. Other Districts rely mostly on the Degree Colleges and DIETs for the bulk of the resource persons. However, some districts like Kolasib have invited experts from various departments like Agriculture, Horticulture, Social Welfare, etc. to speak to the trainees at occasions.

Trainees attending the programmes are given Sitting Allowance/Daily Allowances in all districts with amounts ranging from Rs. $100-200$ per person per day. However, only out-station trainees are given Travel Allowances which is usually calculated as the actual Sumo fares from their places of posting. highlighted:

From the interviews of the administrative staff in all the eight districts, the following points may be

1) The administrative staff at the district RMSA offices had an average experience of 2.5 years under RMSA. The Deputy District Project Coordinators were mostly teachers and Headmasters that had been deputed to the District office. The other administrative staff were mostly clerical staff that were recruited to work in the offices.

2) None of the administrative staff had attended any specific training or workshop for the purpose of organising in-service training programmes.

3) None of the administrative staff had been exposed to RMSA programmes in general and more specifically in-service training programmes, outside the state of Mizoram.

4) All of the respondents opined that the performance of the RMSA project in Mizoram was good and could find no glaring inadequacy in the overall performance. However, most of them did not feel qualified to comment on the comparision of the performances of Mizoram State with other States.

5) Majority of the administrative staff interviewed thought that the in-service training programmes under RMSA was satisfactory.

B. Challenges

Some of the challenges of the RMSA in-service training programme mentioned by the interviewees were -

- Lack of suitable halls

- Lack of adequate number of suitable resource persons

- Unsuitable timing

- Demonetisation scheme

- Lack of resources and facilities

- Lack of interest among the participants

- Transportation problems

- Accommodation problems

- Shortage of teachers

C. Thrust Areas

The following thrust areas were identified as desirable by the interviewees -

- Mathematics education

- Motivation 
- Early release of funds

- Information Technology

- Accommodation facilities

\section{RECOMMENDATIONS}

The investigator has suggested the following recommendations regarding the in-service training programmes for secondary teachers in Mizoram under RMSA in order to improve the efficiency and effectiveness as well as avoid the various pitfalls that may reduce the same and provide an excellent learning atmosphere for the trainees.

1. The relevant authorities may identify suitable skill sets that are needed to organise such training programmes and appoint such qualified persons instead of randomly assigning or recruiting people without any prior specifications. In the very possible scenario that personnel with suitable skill sets are not available, the state project offices must conduct training programmes (or send them to such training programmes organised by other organisations and entities) for people appointed to such posts and positions that are responsible for convening and organising training programmes; so that they develop such skills sets as are necessary to ensure a harmonious and fruitful training programmes for secondary school teachers.

2. The state authorities should send the RMSA personnel involved in organising the training programmes for exposure and educational trips to other states who have been identified as high-performing; to observe and learn from the programmes that are organised in other states as well as to interact with personnel from other places so that they might import some of the best practices from other states.

3. The State authorities must initiate a mechanism for the early release of such funds as are necessary for conducting the training programmes upon which the success of the training programmes hinges in a major way.

4. The State Project Office and other relevant authorities must prepare a vision and mission statement of the training programmes with clear outlines on what the training programmes are supposed to achieve in the long run. The objectives of the programme must be identified and the training programmes tailored accordingly. Also, this must be followed by a system of assessment and evaluation which will ascertain the level to which these objectives have been achieved and what remedial measures need to be taken up. Also, the objectives must be revised on a routine basis to encompass the dynamic nature of secondary education in particular and education in general.

5. The State Project Office may prepare a broad framework for the training programmes that would serve as a guide to all the various districts in the manner of allocation of classes and topics in the training programmes. Such measures would promote a more rounded development in the in-service training programmes while still allowing some flexibility to the district offices.

6. The State as well as district offices may conduct various need analyses of the teachers and schools to incorporate into the training programmes and improve the utility and effectiveness of the in-service programmes. This would also help in the correct application of resources to those areas where it is most needed and thus induce optimum effectiveness and productivity.

7. The State Project Office may recruit a number of highly qualified personnel to serve as resource persons or faculties for the purpose of training teachers in these in-service training programmes along with other allied programmes that may be organised. These faculty members may be circulated among the various districts in a planned fashion so as to ensure that all the districts avail of the expertise of each faculty member. This will reduce the gap between the various districts in terms of manpower availability for the training programmes. Also, such persons may be developed professionally by the project offices as and when required such as sending them for training in national institutions, etc.

8. The State Project Office may prepare several criteria for suitability and eligibility to serve as resource persons in the in-service training programmes. Based on these criteria, the various districts may then shortlist a number of people to serve as the core members of the resource team in their districts. Before the start of the in-service training programmes, such identified persons may be routinely gathered for sensitisation or given additional training as and when required.

9. All Districts should have a permanent or a temporary Teachers Inn at the district headquarters, preferably close to the training centres to provide accommodation for all the out-station teachers who many times had to find shelter with complete strangers in an uncomfortable living arrangement. Fooding may be also be provided at these centres on a subsidised basis.

10. The District Administration may arrange for transportation arrangements in the form of buses or taxis which will transport the participants from their places of residence to the training centres as many of the participants have to often walk for long distances during the training programmes. This problem is further 
compounded by the fact that adequate public transportation is sometimes unavailable in the district capitals and is sometimes costly to the participants.

11. The District Project Offices must arrange for a state-of-the-art training centre with all the latest amenities and facilities wherein to conduct the training programmes. If unable to do so, it may collaborate with other governmental and non-governmental organisations to facilitate the construction or development of such a training facility in their district which may be utilised by several organisations or departments as and when needed.

12. One of the major problems in the in-service training programmes is the timing of the programme which usually is held at the end of the academic session due to the slow release of funds from the relevant authorities. The State Project Office may create a funding mechanism for this purpose so that the training programmes may be conducted at a more appropriate time during the academic calendar.

13. The training programmes might be conducted in a more hands-on and practical oriented approach compared to the theoretical approach currently being carried on. The trainees should be more engaged in the training process with real-world problem-solving activities and hands-on learning activities in actual and simulated situations.

14. Experienced and expert teachers who are well-known in the teaching community for their excellent work may be invited to share their experiences and best practices at the training programmes.

\section{CONCLUSION}

A vibrant and dynamic in-service training programme is sorely needed to improve the effectiveness of the teachers in transacting the curriculum in an effective and efficient manner so as to help the students obtain optimum benefit from their times and effort spent in the schools. The various shortfalls that plague the present system of inservice education of secondary school teachers must be met and dealt with as soon as possible in the most effective manner permitted by the constraints of our resources.

\section{REFERENCES}

1. Alvermann, D. E (1981). A collaborative in-service model: Levels of use of an innovation before and after peer training. American Secondary Education, 11(1), 22-24. http://www.jstor.org/stable/41063387

2. Bala, A. (2017). Rashtriya Madhyamika Shiksha Abhiyan (RMSA) in the state of Himachal Pradesh: An evaluative study. Ph D Thesis, Himachal Pradesh University, Shimla. Retrieved from https://shodhgangotri .inflibnet.ac.in/bitstream/123456789/4593/1/synopsis.pdf

3. Davis, J. C., Biju, S. \& Glory, A. (2014). Teacher training workshops: A capacity building strategy for mainstreaming HIV/Aids prevention education among adolescents. New Frontiers in Education. International Journal of Education, 47(4), 54.

4. Department of School Education and Literacy, MHRD, GOI (2011). PAB Meeting Minutes. https://mhrd.gov.in/sites/upload_files/mhrd/files/minutes/Minutes_of 9th PAB.pdf.

5. Gairola, K. (2013). Management of training and skill development activities of Sarva Shiksha Abhiyan for elementary school teachers of Raipur and Doiwala Blocks of Dehradun District (Uttarakhand). The Primary Teacher Volume XXXVIII Number 1 \& 2 January and April 2013. Retrieved from http://www.ncert.nic.in/publication/journals/pdf_files/ Primaryteacher/PTJan-Apr3012.pdf

6. State Mission Office. Framework for Implementation of Rashtriya Madhyamik Shiksha Abhiyan (RMSA). Mizoram Education Mission Society, Aizawl, Mizoram.

7. Hopfengardner, J. D. \& Potter, A. R. (1992). Staff development: What we are doing - and what we know we should be doing. American Secondary Education, 20(3), 2-7. http://www.jstor.org/stable/41063992

8. Kopcha, T. J. (2010) A systems-based approach to technology integration using mentoring and communities of practice. Educational Technology Research and Development, 58(2), 175-190. http://www.jstor.org/stable/40603155

9. Lalrinliana, H. (2016). Training of Elementary School Teachers in Mizoram in the context of Sarva Shiksha Abhiyan: An Evaluative Study. Ph. D Thesis, Mizoram University.

10. Ministry of Human Resource Development (2016). Framework for Implementation of RMSA. Retrieved from https://mhrd.gov.in/rmsa_guidelines.pdf

11. Pattanshetti, J. S. (2016). In-service Education at Secondary School Level (The present scenario). Neel Kamal Publications Pvt Limited. New Delhi.

12. Patton, W. E. \& Anglin, L. W. (1982). Characteristics of success in high school in-service education. The High School Journal, 65(5), 163-168. http://www.jstor.org/stable/40365055

13. Saeed, M. (1999). The in-service training of primary school teachers in Greece: Views of directors and vice directors of PEK. International Journal of Educational Management, 13(4), 180-186. https://doi.org/10.1108/09513549910278098

14. SCERT, Andhra Pradesh, (1981). Evaluation of in-service training programme for primary teachers in selected government and aided training institutions. In Buch, M. B. (Ed), (1991). Fourth Survey of Research in Education ( $p$ 982). National Council of Educational Research and Training, New Delhi. 